DOI: https://doi.org/10.24867/08CG15Podunavac

\author{
АНАЛИЗА ВАРИЈАНТНИХ РЕШЕЊА И ПРЕДЛОГ ЛОКАЦИЈЕ ЗА \\ ДЕНИВЕЛИСАНУ РАСКРСНИЦУ „ГРАМАЂЕ“ НА АУТОПУТУ Е-75“ \\ ANALYSIS OF VARIANT SOLUTIONS AND LOCATION PROPOSAL FOR THE \\ LEVELING INTERSECTION OF GRAMADJE ON THE E-75 HIGHWAY
}

Никола Подунавац, Факултет техничких наука, Нови Сад

\section{Област- ГРАЂЕВИНАРСТВО}

Кратак садржај - У раду је приказана општа примена u врсте денивелисаних раскрсница, као и анализа варијантних решена денивелисане раскрснице "Грамађа". Извриена је детаљна анализа варијантних решена у смислу локачије изградње денивелисане раскрснице и дата је студија оправданости изградње петље „Грамађе“ како би се утврдило да ће изградња петље имати вишеструку корист. Уместо путовања двотрачним путем, путничка возила, аутобуси као и теретна возила ће бити повезани преко петье „Грамађе“ на аутопут E-75, те ће самим тим бити значајно скраћено време путована.

Кључне речи: Денивелисана раскрсница, анализа, варијантна решења, студија оправданости

Abstract - This work presents the general application and types of leveling intersections, as well as the analysis of variant solutions of the leveling intersection Gramadja." A detailed analysis of variant solutions in terms of the location of the construction of the intersected intersection was made and a feasibility study of the construction of the Gramadja loop was given to determine that the construction of the loop would have multiple benefits. Instead of traveling by two-lane, genger vehicles, buses and heavy rigid vehicle will be connected via the Gramadje loop on the E-75 motorway, thus significantly reducing travel time.

Keywords: leveling intersections, analysis, variant solutions, feasibility study

\section{1. УВОД}

Денивелисане раскрснице се користе при укрштању путева истог или различитог ранга, где је због ранга повезивања путева у мрежу или због величине саобраћајних токова немогуће извести површинске раскрснице.

Повезивање двају путних праваца, под условом одржања режима континуираних токова, захтева просторно раздвајање конфликтних струја, тј. њихово независно вођење у различитим грађевинским нивоима. Денивелисану раскрсницу чине: коловози путева који пролазе кроз раскрсницу, уливи, изливи и повезујуће рампе.

\section{НАПОМЕНА:}

Овај рад проистекао је из мастер рада чији ментор је био доц. др Милош Шешлија.
Саме рампе се, по правилу изводе са смањеним елементима него путеви на отвореним трасама, делом због економичности али првенствено због њихове функције спајања и раздвајања саобраћајних токова.

\section{1. Типови денивелисаних раскрсница}

Денивелисана раскрсница „ТРУБА“ (слика 1 овог прилога) је најједноставнији облик прикључка (трокрака денивелисана раскрсница) и припада функционалном нивоу „Щ“. Садржи све типове рампи: две директне за десна скретања и по једну индиректну и полидиректну рампу за лева скретања.

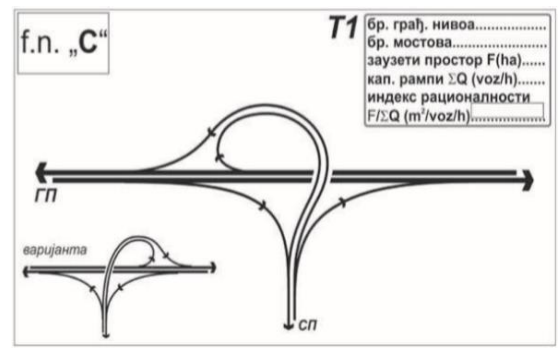

Слика 1. Денивелисана раскрсница „ТРУБА“

\section{2. АНАЛИЗА ВАРИЈАНТНИХ РЕШЕЫА И ПРЕДЛОГ ЛОКАЦИЈЕ}

Предмет ове анализе јесте избор локације за денивелисану раскрсницу Грамађе. За потребе предметне анализе коришћена је и анализирана следећа документација:

- Просторни план подручја инфраструктурног коридора Ниш - граница Републике Македоније

- Просторни план Општине Владичин Хан

- Главни пројекат Аутопута Е-75, Београд - Ниш граница са Северном Мекедонијом, деоница: Владичин Хан - Доњи Нерадовац ('Институт за путеве', а.д. - 2010 год.)

- Пројеката изведеног објекта (ПИО) - Аутопут Е-75, Београд - Ниш - Прешево - граница са Северном Македонијом, деоница: Владичин Хан - Доње Нерадовац, od Km 900+100.90 do Km 926+357.02

Поред претходно побројане документације, за израду Мастер рада на увид су достављене и раније израђиване варијанте и предлози за денивелисану раскрсницу Грамађе. Поменута варијантна решења су у оквиру ове анализе представљене као: 


\section{- Варијанта 1 петље Грамађе и}

- Варијанта 2 петље Грамађе

Оба поменута варијантна решења разматрана су и разрађивана на потезу аутопута између насељених места Грамађе и Семиговац, односно на потезу од $\mathrm{Km} \sim 903+300$ до Km 904+400. Детаљном анализом ова два варијантна решења утврђено је да имају одређене недостатке који ће детаљније бити описани у тексту који следи, а као резултат тога, урађено је треће варијантно решење:

- Варијанта 3 петље Грамађе

\section{1. Локација}

Поред претходно поменуте локације на потезу аутопута од Km 903+300 do Km 904+400, приликом израде Мастер рада је додатно разматрана могућност лоцирања денивелисаног укрштаја и на приближној стационажи аутопута Km 901+500. Међутим, ова локација се није могла наметнути као релевантна због читавог низа недостатака од којих су најважнији:

- веома узак простор између аутопута и паралелног некомерцијалног пута (државни пут IIA 258) који ограничава разраду и дефинисање денивелисаног укрштаја

- близина постојећег пратећег садржаја са бензинском станицом што би условило преклапање уливно/изливних трака рампи петље и пратећег садражаја, а што је у супротности са нормативима

- потребу за измештањем постојећих зидова за заштиту од буке који су изграђени дуж аутопута на овом потезу, а што би додатно угрозило рационалност таквог решења

- већа удаљеност постојећих и планираних индустријских зона које су дефинисане Просторним планом Општине Владичин Хан у односу на локацију денивелисаног укрштаја у близини Грамађе, као и других насељених средина у југозападном делу општине

У складу са свим претходним, као коначно решење, усваја се варијантно решење $\mathbf{3}$, које је приказано на слици 2.

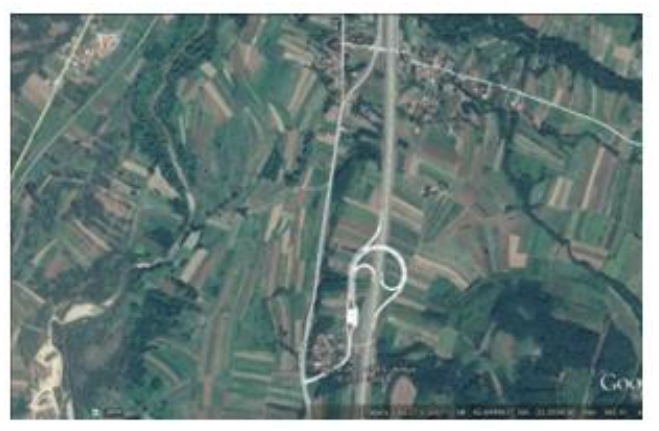

Слика 2. Варијантно решење 3

\section{3. СТУДИЈА ОПРАВДАНОСТИ}

\section{1. Методолошки приступ}

Студијом оправданости одређује се просторна, еколошка, друштвена, финансијска, тржишна и економска оправданост инвестиције за изабрано решење, на основу које се доноси одлука о оправданости изградње.
Ова студија представља економску анализу пројекта разматране петље са циљем да се добију поуздани економски показатељи, на основу којих би се утврдила економска оправданост улагања у њену изградњу. Студија оправданости изградње предметних деоница подразумева поређење процењених (економских) трошкова и користи за предложена техничка решења, као и анализу стандардних економских индикатора. Као и у свим путним пројектима тако и у овом случају од улагања у изградњу пута и његовог коришћења, очекују се уштеде од:

- смањеног времена путовања

- смањених експлоатационих трошкова возила

- смањења броја саобраћајних незгода и њихових последица

- смањеног утицаја на животну средину (загађење ваздуха, климатске промене, бука, итд.)

\section{2. Функционалне и техничке карактерстике пројектних решења}

\section{3. Основна траса аутопута E75}

Постојеће стање аутопутског правца Е75 у зони денивелисане раскрснице "Грамађе" одговара елементима за рачунску брзину $\mathrm{Vr}=120 \mathrm{~km} / \mathrm{h}$.

На предметној деоници, у хоризонталном смислу аутопут је делом у правцу а делом у кривинама радијуса $R=5008 \mathrm{~m}$ односно $\mathrm{R}=3030 \mathrm{~m}$, док jе $\mathrm{y}$ подужном смислу аутопут делом у вертикалној кривини радијуса $\mathrm{Rkv}=17000 \mathrm{~m}$, а делом у паду од $0.34 \%$. Попречни нагиб коловоза је једностран и износи $2.50 \%$.

Нормални попречни профил основног правца аутопута егзистира са следећим елементима:

- ширина возне траке за континуалну вожњу $\mathrm{tv}=$ $3.75 \mathrm{~m}$

- ширина зауставне траке $\mathrm{tz}=2.50 \mathrm{~m}$

- ширина ивичне траке $\mathrm{ti}=0.50 \mathrm{~m}$

- ширина ивичне траке (уз зауставну траку) $\mathrm{ti}=0.20 \mathrm{~m}$

- ширина банкине $b=1.00 \mathrm{~m}$

\section{4. Рампе петље грамађе}

За обликовање рампи у ситуационом плану примењују се правац, круг и клотоида. Осовине рампи дефинисане су на растојању $3.85 \mathrm{~m}$ од десне ивице коловоза.

За рампу R1 Грамађе - Врање предвиђен је директан тип прилаза са елементима геометрије за рачунску брзину $\mathrm{Vr}=30 \mathrm{~km} / \mathrm{h}$. Рампа R2 Ниш - Грамађе је такође директна и пројектована је са елементима геометрије за рачунску брзину $\mathrm{Vr}=60 \mathrm{~km} / \mathrm{h}$. Полудиректна рампа R3 Врање - Грамађе у зони излива пројектована је у складу са елементима који одговарају рачунској брзини $\mathrm{Vr}=60 \mathrm{~km} / \mathrm{h}$, док је индиректна рампа $\mathrm{R} 4$ Грамађе - Ниш у зони улива пројектована за $\mathrm{Vr}=30 \mathrm{~km} / \mathrm{h}$. На делу заједничког вођења индиректне и полудиректне рампе Р4 и Р3 пројектовани су елементи већи или једнаки граничним елементима дефинисаних за $\mathrm{Vr}=50 \mathrm{~km} / \mathrm{h}$.

Обликовање улива и излива на главном правцу изведено је тзв. „паралелним” изливно-уливним 
тракама. Проточни део коловоза је у зони уливаизлива проширен за додатну возну траку ширине $\mathrm{td}=3.50 \mathrm{~m}$, која се простире на дужини пута успоравања (ld), односно убрзавања (la). Она заједно са прикључним делом формира излив, односно улив чије дужине износе Lizl-ul = lc + ld-a.

На основу прилагођене брзине главног правца проистичу следеће грађевинске димензије уливних односно изливних трака на/са аутопута:

- прилагођена брзина главног правца,

- дужина преласка на траку за успорење, односно прелазак са траке за убрзање на возну траку $\mathrm{lc}=60 \mathrm{~m}$,

- дужина пута успоравања односно пута убрзавања износи la $=1 \mathrm{~d}=190 \mathrm{~m}$.

За геометријски попречни профил рампи петље, усвојен је попречни пресек "R1" који омогућава вожњу у колони уз минималне услове за обилажење заустављеног возила (како је приказано на слици 3 ).

GEOMETRIJSKI POPREČNI PROFIL JEDNOSMERNIH RAMPI R1,R2,R3 I R4

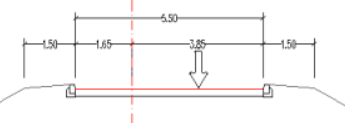

GEOMETRIJSKI POPREČNI PROFIL RAMPI R3 I R4 NA DELU PARALELNOG VOĐENJA

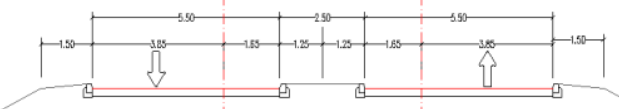

GEOMETRIJSKI POPREČNI PROFIL U ZONI ZAJEDNICKOG VOÐENJA SUH RAMP

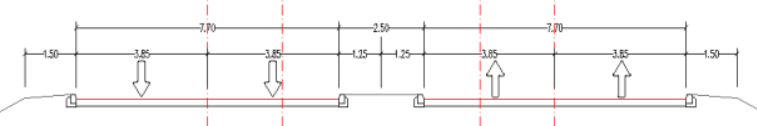

Слика 3. Геометријски попречни профил

Нормални попречни профил рампи петље:

- возне траке $1 \times 3.50=3,50 \mathrm{~m}$

- ивичне траке $1 \times 0.35=0.35 \mathrm{~m}$

- зауставне траке $1 \times 1.65=1.65 \mathrm{~m}$

- банкине $2 \times 1.50=3.00 \mathrm{~m}$

- минимални попречни нагиб $\min \mathrm{ip}=2.5 \%$

- максимални попречни нагиб $\max$ ip $=6.0 \%$

Нормални попречни профил двотрачне рампе:

- возне траке $2 \times 3.50=7.00 \mathrm{~m}$

- ивичне траке $2 \times 0.35=0.70 \mathrm{~m}$

- банкине $2 \times 1.50=3.00 \mathrm{~m}$

- разделни појас $1 \times 2.50=2.50 \mathrm{~m}$

\section{5. Ситуационо решење}

Предметно решење денивелисане раскрснице представља раскрсницу типа „труба“, при чему су директни токови предвиђени за смерове Ниш-Грамађе и Грамађе-Врање, полудиректни ток за смер ВрањеГрамађе и индиректни за смер Грамађе-Ниш. Веза петље са паралелним некомерцијалним путем, државним путем IIA реда бр. 258 предвиђена је на km $61+930.50$, на локацији постојећег прикључка локалног пута за насеље Семиговац. Предметним решењем предвиђена је реконструкција поменутог прикључка уз проширење ивичне геометрије како би се омогућио пролаз тешког теретног возила, шлепера, који се за предметни денивелисани укрштај прописује као меродавно возило за пројектовање.

\section{6 НАПЛАТНИ ПЛАТО}

Поред решења денивелисане раскрснице овим Мастер радом предвиђено је и решење платоа наплатне станице. Наплатни плато је формиран у правцу и благом подужном нагибу од $0.5 \%$. Пројектована су 3 оства за кабине за наплату путарине односно 4 саобраћајне траке. Острва су пројектована у складу са захтевима модернизованог система наплате путарине и дужине су $52 \mathrm{~m}$, са размаком између острва od $3.5 \mathrm{~m}$. Крајња лева и крајња десна саобраћајна трака је пројектована за вангабаритни пролаз и ширине је $4.5 \mathrm{~m}$. Ширина коловоза код управне зграде је $6.0 \mathrm{~m}$. Ветонски коловоз је пројектован у дужини од $100 \mathrm{~m}$, због уклапања бетонских плоча.

\section{7. Димензионисање коловозне конструкције}

Димензионисање коловозне конструкције извршено је према стандарду СРПС У.Ц4.015/1994 "Пројектовање и грађење путева, Димензионисање нових флексибилних коловозних конструкција" и СРПС У.Ц4.014/1994 "Пројектовање и грађење путева, Димензионисање нових цементнобетнских неармираних коловозних конструкција" софтверским пакетом AASHTOWare DARWin 3.1 који је израђен као оригинална софтверска подршка за пројектовање према методологији из AASHTO Guide for the Design of Pavement Structures 1993 od strane American Association of State Highway and Transportation Officials (AASHTO). На слици 4 дат је приказ пројектних решења коловозне конструкције за петљу „Грамађа“:
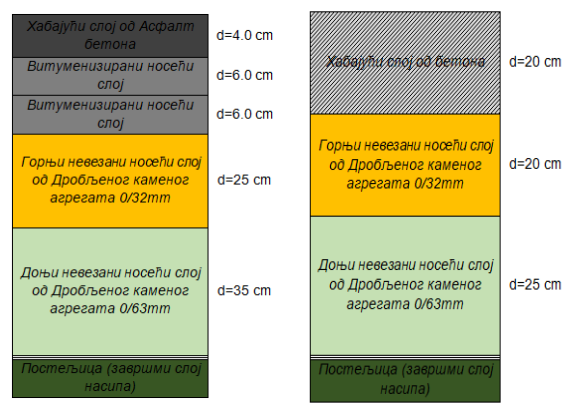

Слика 4. Флексибилна коловозна конструкција (лево), крута коловозна конструкција (десно)

\section{8. Анализа трошкова и користи}

Анализа трошкова и корити (ЦБА) састоји се из три дела:

- техничко оперативни део у коме су идентификовани параметри, техничке, функционалне и захтевне карактеристике пројекта, 
- економске анализе, која је, почевши од финансијске анализе која служи за идентификацију свих прихода и расхода стварне и релативне тржишне цене, примењује низ исправки које нам омогућавају да пређемо са тачке гледишта инвеститора на тачку гледишта друштва као целине,

- финансијска анализа која представља почетак анализе трошкова и прихода, а која води исту са тачке гледишта инвеститора.

Препоручени референтни период, према Упутству за израду анализа трошкова и користи коју је објавило ЈП Путеви Србије, а израђено у складу са Упутством за израду анализа трошкова и користи од стране Европске комисије, предлаже да је период експлоатације, који је неопходно детаљно обрадити анализом трошкова и користи, 20 година.

Анализа трошкова и користи за пројекте који траже финансирање од финансијских институција морају показати да је пројекат:

- вредан финансирања и

- треба да буде финансиран

\subsection{0. Прорачун интерне стопе рентабилитета}

Интерна стопа повраћаја (The internal rate of return (IRR)) jе вредност ,i“ за коју је нето садашња вредност једнака нули. Другим речима, вредност интерне стопе повраћаја добијена је решавањем следеће једначине:

$$
\sum_{\mathrm{t}=0}^{\mathrm{n}} \mathrm{a}_{\mathrm{t}} \mathrm{S}_{\mathrm{t}}=\frac{\mathrm{S}_{0}}{(1+I R R)^{0}}+\frac{\mathrm{S}_{1}}{(1+I R R)^{1}}+\ldots+\frac{\mathrm{S}_{\mathrm{n}}}{(1+I R R)^{\mathrm{n}}}=0
$$

\subsection{1. Закључак економске анализе трошкова и користи}

Анализа трошкова и користи је урађена за експлоатациони период од 20 година. Прва година експлоатације је 2021. Последња година која је узета у обзир приликом израде ове анализе је 2040.

Економска дисконтна стопа је 8\% препоручена Упутством за израду анализа трошкова и користи, издатим у сарадњи са ЈП Путеви Србије и Министарством инфраструктуре .

Инвестициона вредност изградње денивелисане раскрснице „Грамађе“ на аутопуту Е75 је РСД 356.389.211.

Показатељи економске анализе су $\mathrm{ENPV}=81.292 .366$ PCД, $\mathrm{EIRR}=10,74 \%, \mathrm{~B} / \mathrm{C}=1,25$.

На основу анализе економских показатеља може се констатовати да изградња петље Грамађе има економску оправданост.

\section{4. ЗАКЉУЧАК}

Циљ Мастер рада је био да анализира економску потребу за улагањем у изградњу предметне петље „Грамађе“ која се налази на аутопуту Е-75 (државни пут IA-A1), и да се анализирају користи за друштво и одрживост пројекта избором локације петље.

Петља "Грамађе" је веза јужних и југозападних делова подручја општине (у јужном делу општине налази се индустријска зона “Југ”) и градским насељем Владичин Хан (преко државних путева IIA 258 и IIB 473), као и градским насељем Сурдулица, преко државног пута IIB 441.

Уместо путовања двотрачним путем путничка возила, аутобуси као и теретна возила ће сада бити повезани преко петље Грамађе на аутопут Е-75, те ће самим тим бити значајно скраћено време путовања, како за путнички тако и за теретни саобраћај. Дозовољене брзине ће се променити са 50 - $80 \mathrm{~km} / \mathrm{h}$, на појединим деоницама, на до $130 \mathrm{~km} / \mathrm{h}$ за путничке аутомобиле. Према томе, очекује се скраћење времена путовања, према тренутним условима на терену.

\section{5. ЛИТЕРАТУРА}

[1] Приручник за пројектовање путева у Републици Србији, Функционали елементи површине путева - Денивелисане раскрснице

[2] Правилник о условима које са аспекта безбедности саобраћаја морају да испуњавају путни објекти и други елементи јавног пута (“Службени гласник РC", бр. 50/11).

[3] Закон о путевима, Сл. гласник Р.Србије бр. 41/18

[4] Идејни пројекат денивелисане раскрснице „Грамађе“ на аутопуту Е75 на К.О. Грамађе

\section{Кратка биографија:}

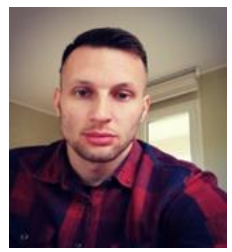

Никола Подунавац рођен је у Новом Гаду, Б и Х, Република Српска 1993. године. Мастер рад на Факултету техничких наука из области Грађевинарство одбранио је 2019. год. 